\title{
Sini-Emilia Asikainen
}

\section{Sota jäi elämään naisen roolissa ja mentaliteetissa}

\begin{abstract}
ABSTRAKTI / ABSTRACT
Talvi-ja jatkosota aiheuttivat radikaalin muntoksen ibmisten arkeen, rikkeoen naisten ja miesten välisen työnjaon. Sota ja sitä seurannut jälleenrakennuskausi lisäsivät naisten vastuuta nïn perheestä, kodista kuin elannosta buolebtimisesta, mikä näkyy yhä nykypäivänä. Naisten tuli uhrata omat tarpeensa muiden hyvinvoinnin puolesta. Sodan jälkeen työtä riitti, ja tuon ajan lapset saivat pärjätä monesti omillaan. Pienemmistä sisaruksista buolebtimista odotettiin lähinnä isosiskoilta ja tytöt auttoivat arjen askareissa.

Artikelelissa tarkastellaan talvi-ja jatkosodan ylisukupolvisia vaikutuksia naisen rooliin ja mentaliteettiin suurten ikäluokkien naisten muistitiedon kautta. Suurten ikäluokkien naisilla on näbtävissä buolebtijan ja vastuunkantajan rooleja sekä sinnikkeyyden ja selviytymisen mentaliteettia. Hyvinvointivaltiokaudella Suomessa on ollut enemmän resursseja pobtia esimerkiksi lasten kasvatusta, ja millaisia ominaisunksia omalla toiminnallaan voi ylisukupolvisesti siirtää. Kuitenkin vielä suurten ikäluokkien tyttäret ovat omaksuneet vastuuntunnon mentaliteetin, jota ybteiskunnalliset rakenteet pitävät yllä.
\end{abstract}

naisen rooli, mentaliteetti, ylisukupolvisuus, suuret ikäluokat

Sini-Emilia Asikainen, VTM (Helsingin yliopisto), sissi.asikainen@gmail.com 


\section{Johdanto - sodan vaikutukset naisen rooliin}

Vaikka sodan jälkeen syntyneillä suurten ikäluokkien naisilla ei ole omakohtaista kosketuspintaa sotaan, ovat sen vaikutukset silti heijastuneet heidän elämäänsä. Myös nuoremmilla naisilla voidaan ajatella näkyvän sotien ja jälleenrakennuskauden myötä omaksuttuja rooleja ja mentaliteetteja, sillä ne ovat siirtyneet äidiltä tyttärelle ylisukupolvisesti vanhemmuuden ja kasvatuksen, lapsuuskokemusten ja äidin esimerkin sekä yhteiskunnan asettamien vaatimusten kautta. ${ }^{1}$

Talvi- ja jatkosodan aikana kotirintaman arki oli enimmäkseen naisten vastuulla, kun työikäisiset miehet sotivat rintamalla. Aiempi naisten ja miesten välinen työnjako murtui ja naisten työtaakat kasvoivat entisestään. 1940-luvun agraari-Suomessa moni työ tehtiin ilman koneiden apua. ${ }^{2}$ Enemmistö rintamamiehistä oli alle 40-vuotiaita, ja koska väestörakenne oli vielä nuori, oli rintamallelähtö melkoinen mullistus, jolla oli vaikutusta eritoten perheenperustamisiässä oleviin ja lapsiperheisiin. ${ }^{3}$ Naisten lisäksi kotirintamalle jäi lähinnä alaikäisiä lapsia ja vanhempaa väkeä. Pientiloilla aputyövoiman palkkaaminen oli harvoin mahdollista. ${ }^{4}$ Isommat lapset auttoivat tilan töissä, mutta pienemmät vaativat äidin tai isompien sisarusten huolenpitoa. Rintamamiehiäkin pyrittiin kiireisimpinä aikoina päästämään hoitamaan kotitilan kylvöä ja sadonkorjuuta, jos se vain oli mahdollista. ${ }^{5}$

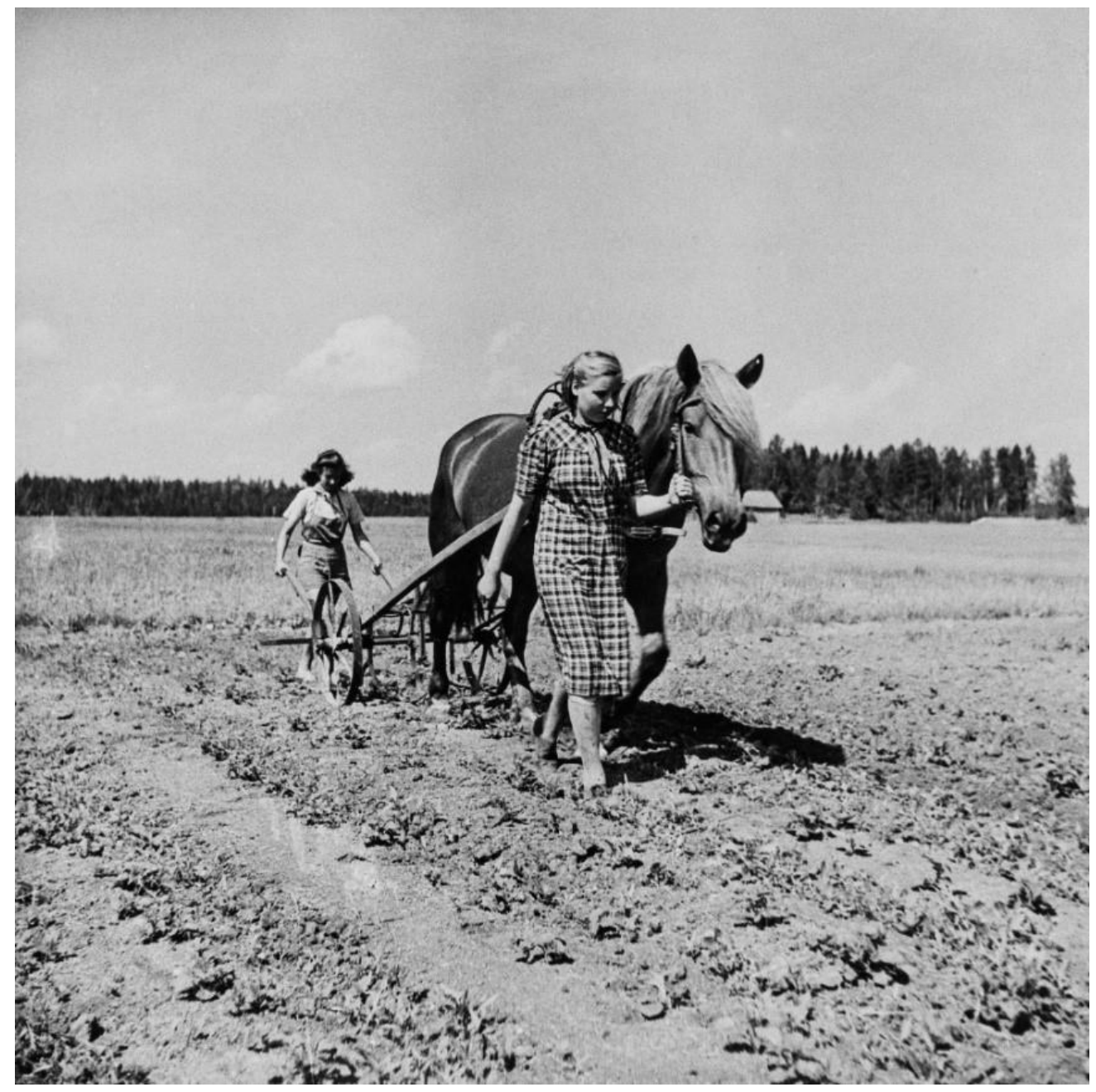

Kuva 1. Nuoret naiset maataloustö̈ssä Pirkekalassa vuonna 1941. CC BY 4.0. Museovirasto, Kansatieteen kuvakokoelma. 
Sodan jälkeen naisia kehotettiin olemaan rasittamatta rintamalla kärsineitä miehiä liikaa. Naisten tehtävänä oli hoitaa kodin töiden ja lasten lisäksi myös veteraanimiehiä fyysisine ja psyykkisine haavoineen, mikä kasvatti usein huomattavastikin työtaakkaa. Vaimojen ja lasten tuli myös kestää veteraanien jälkioireilua. ${ }^{6}$

Sota loi pohjaa keskustelulle naisten ja miesten välisestä työnjaosta ja naisten käsitys yhteiskunnallisesta asemastaan muuttui. Käytännössä sota ja jälleenrakennuskausi kuitenkin lisäsivät eriarvoisuutta - työt jaettiin miesten ehdoilla - sekä vahvistivat naisen huolehtijan, hoivaajan ja vastuunkantajan roolia. ${ }^{7}$

Tarkastelen suurten ikäluokkien perimää roolia ja mentaliteettia analysoimalla laadullisen sisällönanalyysin avulla 12 naisen vuonna 1991 kirjoittamaa omaelämäkertatekstiä sekä samojen naisten kirjallisia haastatteluvastauksia vuodelta 2020. Naisen rooleja voivat olla esimerkiksi vaimo, äiti, kotitaloustöiden ja ansiotyön tekijä sekä yhteiskunnallinen osallistuja. Roolin muodostumiseen vaikuttavat esimerkiksi yhteiskunnan normit sekä sukupuoli, ikä, elämäntilanne ja siviilisääty. Mentaliteetilla tarkoitan osin tiedostettua, kuitenkin paljolti tiedostamatonta, ajattelutapaa ja elämänasennetta, jotka vaikuttavat yksilön toimintaan. Mentaliteetti on myös kollektiivinen ilmiö; se muotoutuu vuorovaikutuksessa yksilöä ympäröivän yhteiskunnan kanssa. ${ }^{8}$

Rajasin tarkastelun maalaistaustaisiin suurten ikäluokkien naisiin. He ovat lähtöisin melko köyhistä oloista, usein pientilalta, ja heidän lapsuutensa oli työntäyteinen. ${ }^{9}$ Naiset olivat omaelämäkertojen kirjoitushetkellä 40-44-vuotiaita ja enemmistö heistä eli lapsiperhearkea. Kirjalliseen haastatteluun tavoitettiin viisi naista. Niiden avulla sain kiinnostavaa tietoa siitä, kuinka nämä henkilöt reflektoivat seitsenkymppisinä lähes 30 vuotta aiemmin kirjoittamiaan omaelämäkertatekstejä. ${ }^{10}$

Sotien ylisukupolvisten sosiaalisten vaikutusten tutkiminen on ollut Suomessa melko vähäistä, vaikka kyseessä on yhteiskunnallisesti merkittävä ilmiö. Myös naisten näkökulma sodan perintöön kaipaa lisää tutkimusta eikä suomalaisnaisten sodanaikaisten kokemusten ylisukupolvisuutta ole ennen tutkittu. Ville Kivimäki on esittänyt, että sodanjälkeisen Suomen "kestävin osa - - elää yhä yhteiskunnan rakenteissa, mentaliteeteissa ja suomalaisessa kulttuurissa." ${ }^{11}$ Vuonna 2018 Kivimäki ja Tiina Kinnunen toivat esiin, että sodan vaikutuksia olisi tarpeen katsoa "useiden sukupolvien ketjussa". ${ }^{12}$

\section{Omillaan pärjääminen lapsesta saakka}

Sotien jälkeen maatilan moninaiset tehtävät työllistivät monen äidin enemmän kuin täyspäiväisesti. Suurten ikäluokkien nimityksen mukaisesti lapsia syntyi paljon, etenkin maalaisperheisiin. Tästä syystä moni joutui itsenäistymään aikaisin ja pärjäämään omillaan. ${ }^{13}$ Moni äiti joutui uupumuksen ja pahimmillaan terveyden pettämisen partaalle työn, veteraanimiehen ja lasten hoitamisen aiheuttaman taakan seurauksena. Uupumus vaikutti äitien mielialaan. ${ }^{14}$ Vuonna 1947 syntynyt Tuula muistelee vanhempiaan:

Vanhemmat eivät osallistuneet harrastuksiimme, mutta eivät niitä kieltäneetkään. Haikeata toki oli joskus, kun tiesi, etteivät he tule koulun jubliin eivätkä tervebtimään seurakunta- tai partioleireille. Heillä oli niin kovasti työtä. ${ }^{15}$

Osa jälleenrakennuskauden äideistä onnistui kiireestä huolimatta olemaan läsnä lapsilleen, mutta toisten äidit jäivät etäisiksi. Vuonna 1950 syntynyt Ella muistelee haikeana toivoneensa, että "edes joskus olisivat oman äitini kiireiset kädet ehtineet rukoukseen kanssani sängyn laidalle." " Vuonna 1948 syntyneellä Raijalla oli kolme sisarusta ja hän kertoo äitinsä olleen töiden vuoksi kiireinen ja "pelottavan etäinen". Katkelmassa tulee hyvin esiin 1950-luvun alun maalaisnaisen työtaakka. 


\begin{abstract}
Ä̈ti vietti aikansa enimmäkseen ulkona - - joten hän jäi pakostakin etäiseksi. Silloinhan maatö̈ssä työt vielä tehtiin käsin ja ihmisvoimin. - - Niibin aikoibin vielä isä tarvitsi äitiä pellolla apunaan - lisäksi äidin vastuulla olivat lehmät, kanat, siat, milloin mitäkin - - Äiti teki töitään pelottavan etäisenä eikä juuri kajonnut meidän elämäämme, mitä nyt jakoi töitä. - - Meidän lasten odotettiin pysyvän poissa jaloista. Aikuisilla oli omat huolensa ja kiireensä. ${ }^{17}$
\end{abstract}

Vaikka Aino (synt. 1950) oli ainoa lapsi, oli hänen äitinsä niin kiireinen, että Aino joutui pärjäämään omillaan pienestä asti. Hän ei halua tehdä samaa virhettä omien lastensa kanssa.

Piti olla kiltti ja tottelevainen, mutta kuitenkin huolebtia itse itsestään. Piti pärjätä yksin. Ä̈ti oli töissä ja isän tehtävänä ei ollut huolehtia minusta, vaikea oli välillä kotona. - - Koulunkäynnistä piti buolebtia. - - Äitini yritti täyttää oman aikansa naisen roolin vaatimukset omassa elämässään siltä osin kuin pystyi. Tuohon aikaan naisen rooli liittyi lähes täysin kotiympäristöön; lasten hoitoon miehen buoltoon, kodin siisteyteen ja ilmapiirïn. Äitini hoiti työnsä aina byvin, hoiti myös kodin ja myöhemmin isänikin, kun bän sairastui. Minä jäin sivuun. Hän teki tunnollisesti kaiken mitä bänelle määrättiin - - Toisin kuin äitini, olen yrittänyt olla lasten lähellä ja kunnnella beitä. ${ }^{18}$

Koulumatkoista yksin selviytyminen oli tavallista suurten ikäluokkien lapsuudessa. Vuonna 1949 syntynyt Helena H. kertoo:

Opin kulkemaan koulutieni, vaikeka se tuntuikin raskaalta, tulihan siinä edestakaista matkaa kunsi kilometriä päivässä. Olin vain metrin mittainen tyllerö, joten ei minulla voimia ollut liikeaa, mutta sisua sitäkin enemmän. - - Talvella kuljin bïbtämällä metsän läpi ja ibmettelen, kuinka en osannut pelätä mitään. ${ }^{19}$

Jälleenrakennuskaudella lasten odotettiin usein olevan itsenäisiä ja omatoimisia. ${ }^{20}$ Sen seurauksena lapsi on voinut kokea jääneensä ilman aikuisten tukea, tai sitten hän on voinut kehittyä omatoimiseksi ja kyvykkääksi.

\title{
Vahva ja ahkera nainen selviytyy ja uhrautuu
}

Naisten jo ennestään suuri työtaakka kasvoi sekä sodan aikana että sen jälkeen. Miesten ollessa rintamalla maalaisnaisen rooli laajentui kotitilan piiristä ennen miesten hallitsemiin työtehtäviin, ansiotyöhön sekä arjen organisaattorin ja vastuunkantajan rooliin. Seija-Leena Nevalan ja Kirsi-Maria Hytösen mukaan maalaisemännät tekivät "niin isännän, piian kuin renginkin tehtävät." Naisista tuli itsenäisempiä, kun he tottuivat pärjäämään ilman miehiä. ${ }^{21}$

Sodan jälkeen suurten ikäluokkien syntyminen, jälleenrakennus ja uusien tilojen perustaminen aiheuttivat sen, että työtä oli vieläkin enemmän. Työhön kykenevät miehet ahkeroivat kyllä, mutta yli 90000 miestä oli kaatunut ja 100000 haavoittunut tai saanut pysyvän vamman. Tällöin naisten ja miesten työjärjestys saattoi muuttua pysyvästi. Fyysiset tai psyykkiset traumat haittasivat monen miehen työntekoa toiset taas saattoivat pyrkiä unohtamaan sodan kauheudet upottautumalla uurastukseen. Naisia velvoitettiin olemaan ahkeria ja joustavia sekä jaksamaan. ${ }^{22}$ Myös selviytyminen oli keskeistä. Pia Olssonin kertoo erään naisen muistelleen sota-aikoja seuraavasti: "Nyt jälkeenpäin tuntuu aivan ihmeelliseltä, että me jaksettiin ja kestettiin, kun kaikesta oli vielä pula ja puute."23 


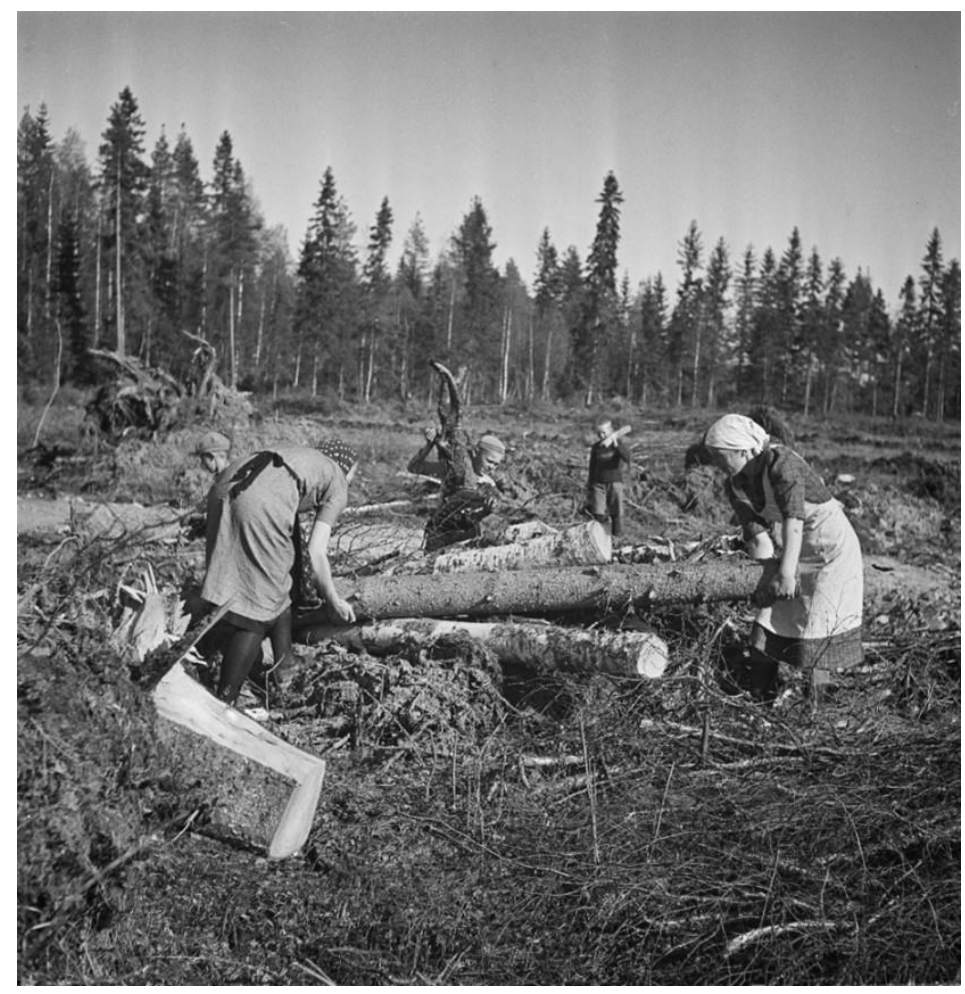

Kuva 2. Pekeka Kyytinen 1941. Naiset ja lapset raivaustö̈ssä Valtimolla. CC BY 4.0. Museovirasto, Kansatieteen kuvakokoelma.

Miehet olivat tehneet merkittäviä uhrauksia rintamalla ja kotirintaman uhrauksia pidettiin siihen nähden pieninä. Jälleenrakennuskauden julkisessa keskustelussa erityisesti naisilta odotettiin uhrautumista. Holmilan ja Mikkosen mukaan "Merkittävintä ajan julkikeskustelussa oli se, että kaikki vaatimukset, ohjeet ja uhraukset oli kohdistettu naisiin, ja miehet pääsivät tavallaan kuin koira veräjästä." ${ }^{24}$ Sotien jälkeen naisten tuli kestää miesten oireilua, kuten hermostuneisuutta, painajaisia, uskottomuutta, vetäytymistä, arvaamatonta ja aggressiivista käytöstä sekä runsasta alkoholinkäyttöä. ${ }^{25}$

Vahvalla ja ahkeralla naisihanteella on Suomessa pitkä historia ja sodan myötä se vahvistui. ${ }^{26}$ Sotasukupolven naiset ovat esimerkkinsä kautta välittäneet tyttärilleen kuvan ahkerasta naisesta, joka hoitaa velvollisuutensa mukisematta. Maalaistaustaiset suurten ikäluokkien naiset tottuivat jo lapsina työntekoon. Nimimerkkiä Sopuli käyttävä vuonna 1947 syntynyt nainen kuvailee äitinsä olleen ahkeroiva moniosaaja ja "oikea selviytymisen mestari", jonka vastuulla olivat sekä taloudenpito, karja että kananmunabisnes. "Minulla on tunne, että hän hallitsi nämä asiat." ${ }^{, 27}$ Ella kokee perinensä äidiltään ahkeruuden, sinnikkyyden ja emännän mallin. ${ }^{28}$ Vuonna 1947 syntynyt Saara kuvailee äitinsä olleen "henkisesti luja ja vahva" sekä sitkeä. Hän kokee saaneensa perintönä osan äitinsä sitkeydestä.

\section{Ä̈ti oli sitkeä, bän osallistui kaikkeiin mabdollisïn ja mabdottomiin tö̈bin erilaisia apukeinoja kek- sien. - - Kyllä minullakin jonkinlaista sitkeyttä on - - ${ }^{29}$}

Moni omaelämäkerta sisältää sinnikkyyttä ja selviytymistä vaativia koettelemuksia, kuten kiirettä, terveysongelmia ja huonojen avioliittojen sietämistä. Esimerkiksi Raija sinnitteli 16 vuotta avioliitossa, jossa koki jäävänsä vaille rakkautta ja arvostusta. Hän kantoi lähes yksin vastuun yhteisistä lapsista ja näiden elatuksesta. ${ }^{30}$ Naiset kantavat vastuuta ja pitävät huolta lastensa lisäksi miehistään. Vuonna 1947 syntynyt Sisko kesti vuosien ajan alkoholistimiehensä vastuutonta käytöstä.

Ryypyn bän otti siksi, kun toisetkin työkaverit ottavat - - se ei ole mies eikä mikeään, joka ei ota - bän pelkäsi--joutuvansa sunnsoiton kobteeksi. Näin alkoboli objaili ubriaan-- Kyllä tuli monta kertaa tehtyä itsetutkiskelua siitä, että jos minussakin on syytä miebeni juomiseen. Onneksi oli voimia kestää- - ${ }^{31}$

Sisko kokee omaksuneensa "sitkeyden selviytyä elämän vaikeissakin tilanteissa" äidiltään. ${ }^{32}$ Myös lapsiperhearki voi vaatia selviytymistä. Sisko kertoo: 
[T]arvittiin taas loputtomiïn kestävää äitiä, sillä tyttö buuti 2 tuntia ja nukkui 10 minuttia ensimmäiset 3 vuotta. - - Valvoin yöt lapsen kanssa. Koitin kaikin keinoin hillitä bänen buntoaan, että kanssaibmiset voisivat nukkua. ${ }^{33}$

Vuonna 1949 syntynyt nimimerkki Helena on kirjoittanut omaelämäkertansa kolmannessa persoonassa. Hän muistelee:

Helena ibmetteli mistä hän sai vielä undelleen voimia, kun [lapsi] jälleen sairastui - - bän jaksoi kuitenkin taistella, lääkäriltä lääkärille, sairaalasta sairaalaan. Istua lapsen vuoteen vierellä leik.kausten jälkeen, lohduttamassa, uskomassa ja toivomassa. ${ }^{34}$

Selviytyminen vaikuttaa olevan yleisin omaelämäkerroissa esiintyvä mentaliteetti. Antti Malinen kuitenkin huomauttaa, että naisilla on tapana jäsentää elämänsä "vaikeuksien kautta voittoon" -tarinaksi riippumatta siitä, miten se on sujunut. "Näin oma elämä on vastannut itsenäisesti pärjäämistä ja selviytymisen eetosta korostavaa suomalaista kulttuuria." 35

Matti Kortteisen mukaan naiset näkivät uhrautumisen olevan moraalisesti oikeaa toimintaa, joka kytkeytyy myös "kunnon naisena" olemiseen. Kortteisen mukaan se ei tarkoita, että nainen olisi alistetussa asemassa, sillä hän uhrautuu omasta halustaan. "Ensin autetaan äitiä, sitten isänmaata, sitten miestä sitten lapsia. Aina autetaan - - ja uhrataan oma elämä - - Lähes aina tuloksena on liki loppumaton uhrautuva työskentely toisten eteen." ${ }^{36}$ Aineiston naisista uhrautumista esiintyy noin puolella. Nimimerkki Helena kertoo:

Nyt Helena hoiteli sisarustensa lapsia - - äit kävi heillä, kun tarvitsi yösijan ja autokyydin - - be olivat bänelle "botelli ja taksi." Myöhemmin naapurit ja [tuttavat] liittyivät tähän joukkooon. Tukanleikekun tai lapsien boidattaminen Helenalla alkoi olla monelle jo nïn itsestäänselvyys, ettei edes kiitoksen sanaa lausuttu. - - Helena kuunteli toisten ongelmia, istui tuntikausia pubelimessa, niin yöllä kuin päivälläkin. - - Kukaan ei kysynyt: "Kuinka sinä voit, mitä sinulle kuuluu?" - - kaikki he bakivat bänestä jotakin. - - Hän antoi itsestään kaiken aikaa saamatta tilalle mitään $-{ }^{37}$

Myös Helena H. uhrasi omat tarpeensa perheensä eteen:

En ottanut itselleni mitään harrastuksia vaan keskityin kokonaan perbeeseeni. - - Halusin - - olla kunnon vanhan ajan ä̈ti, joka tekee kaiken itse - - oikea äiti, jolla on aina kotiruokaa, kun perhe tulee kotiin ja pullaa pakastin täynnä. Unohdin omat tarpeeni. Kuntoilu jäi vähïn ja väsyin aina enemmän. - - unobdin kokonaan oman itseni huoltamisen, koska perbeeni ei saanut kärsiä minun väsymisestäni. ${ }^{38}$

Sotasukupolvea nuoremmat naiset pohtivat kuitenkin jossain määrin uhrautumisen järkevyyttä. ${ }^{39}$ Suuret ikäluokat saattavat tiedostaa, että heidän äitinsä uhrautui, eivätkä itse halua tehdä samoin. Esimerkiksi Sisko ajattelee äitinsä olleen "liiankin uhrautuva". ${ }^{40}$ 


\section{Vastuun kantava ja huolehtiva nainen}

Jälleenrakennuskaudella oli tärkeää säilyttää yhteiskunnan vakaus, minkä takasi perheiden sisäinen vakaus. Perheen ydin puolestaan oli äiti. Velvollisuuden täyttämisen narratiivi kohdistettiin julkisuudessa erityisesti naisiin. Naiset saattoivat olla vastuussa myös miesten onnesta. Rintamalta palanneille miehille tuli puhua "lempeästi, ystävällisesti ja kohteliaasti” eikä heiltä saanut ensi alkuun edellyttää liikoja. Naisilta odotettiin erilaista vastuun kantamista kuin miehiltä, joiden ensisijaisena tehtävänä oli työnteko ja perheen elatus - tosin tämä vastuu alkoi sotien seurauksena koskea yhä enemmän myös naisia. Naisten tehtävänä oli kodin ja arjen ylläpito sekä miestensä tukeminen. ${ }^{41}$ Raija kokee epäonnistuneensa avio-onnen luomisessa.

[K]aikista yrittämisistäni buolimatta epäonnistuin mitä syvimmin elämäni tärkeimmässä ihmissubteessa; subteessani mieheeni - -

Ainoa onnen edellytykseni on olla tärkeä jollain tavalla toiselle tai toisille. Ellen tunne olevani sitä, abdistun. Elämä ei tunnu mielekkeäaltä ilman sitä tietoisuntta.

Siksikö hukutin mieheni huolenpitoon ja läheisyyteen. Siksikö passaan lapsenikin pilalle $-{ }^{42}$

Suurten ikäluokkien naiset näyttäytyvät kirjoituksissaan vastuun kantajina. ${ }^{43}$ Aino muistelee rooliaan elämänsä varrella. Katkelmassa kiteytyy naisen monitahoinen rooli.

Parisubteessa roolini on ollut kaiken koossapitävä voima. Roolejani ovat olleet kodinhoitaja, siivooja, lastenhoitaja, leipuri, koulunkäyntiavustaja, erotuomari, äiti ja puoliso. - - Mielestäni vastuullisuus on ollut peruste sille, että roolit ovat vaibdelleet. Selviytyminen arjen vaatimuksista, päryä̈minen ybteisk.unnallisissa muntoksissa ja täysin undenlaisten asioiden oppiminen (tietotekniikeka) ovat tuoneet unsia rooleja. Tarve on tullut ulkopuolelta enkä ole siihen voinut aina vaikuttaa. Sütä on seurannut kriittisyys omaa tekemistä kohtaan ja välillä buono omatunto. Joskus on tuntunut, että elämä on ollut pelk.kää suorittamista. $^{44}$

Tuula koki velvollisuudekseen huolehtia isästään, joka oli palvellut sodassa. Tässäkin katkelmassa tulee esille edellisessä lainauksessa esille tullut huono omatunto, joka tuntuu myös olevan ylisukupolvinen vaiva.

[Y]ritin hakea kaiken sen avun, mitä ybteiskunta tarjosi, kotiavustajat, kotisairaanhoitajat, vammaisvaipat ja tilapäispaikat vanbainkodissa. - - En voinut vanhaa ibmistä, joka oli sodat sotinut puolestamme, ilman hoitoakaan jättää. Aina oli buono olo. Jos oli isän kanssa väsytti ja kyllästyttti. Jos tuli sieltä pois, oli buono omatunto. ${ }^{45}$

Sopuli muistelee lapsuudessaan olleen "kansalaisvelvollisuus tai maan tapa, että perheessä on enemmän kuin yksi lapsi”. ${ }^{46}$ Pia Olssonin mukaan naiset olisivat halunneet hankkia vähemmän lapsia kuin yhteiskunnalliset normit sallivat. Siksi he saattoivat kokea lapset myös taakkana. ${ }^{47}$

Lapsista huolehtimista ei odotettu ainoastaan perheenäideiltä, vaan usein myös muilta naisilta, kuten isoäideiltä ja siskoilta. ${ }^{48}$ Pikkusisarukset olivat usein isosiskojen vastuulla opittuaan kävelemään. ${ }^{49}$ Moni suurten ikäluokkienkin naisista oppikin huolehtijan rooliin jo lapsuudessaan. Vuonna 1950 syntynyt Kirsti muistelee, että kun hänen vanhemmat sisarensa saivat lapsia, "tuntui olevan itsestään selvää, että 
minä niitä vauvoja tuuvittelin". ${ }^{50}$ Alle parikymppinen Helena H. hoiti opintojensa lisäksi nuorempia sisaruksiaan äidin ollessa töissä:

Kävin vuoden koulua, boidin iltaisin nuoremmat sisaret, kun äiti oli töissä. Isään ei voinut luottaa. Hän tuli kotiin, kun bänelle sopi. En voinut läbteä juuri minnekään, koska en uskaltanut jättää nuorempia sisaruksia aivan keskenään. ${ }^{51}$

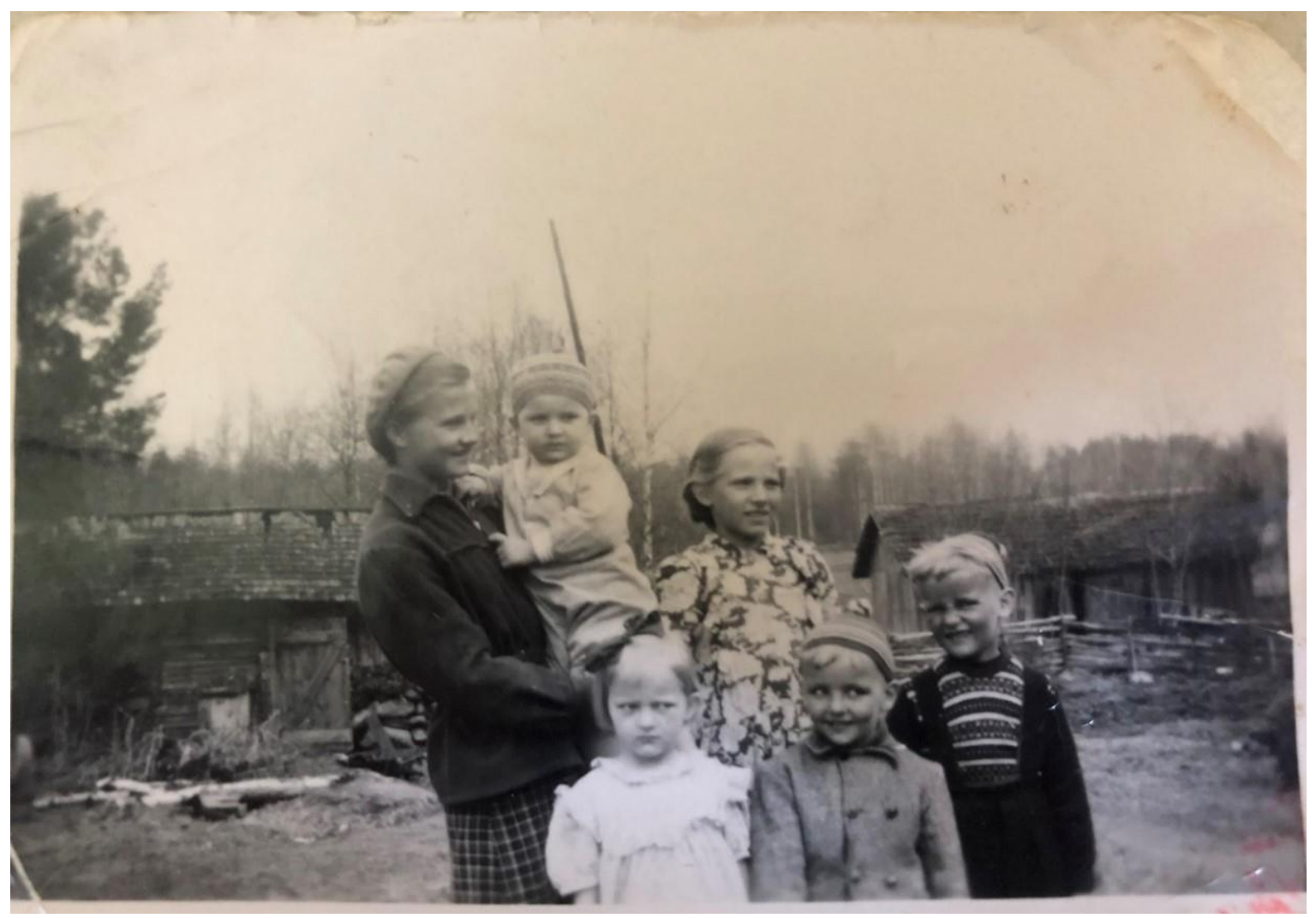

Kuva 3. Rä̈̈kekylä 1954. Kuvassa vasemmalla sisarusparven toiseksi vanhin. Hän syntyi, kun talvisotaa oli kestänyt kolme kunkautta. Sylissään hänellä on perheen nuorimmainen. Yksityinen kuva-albumi.

Saara muistelee lapsuuden rooliaan:

Minun lapsundessani tytöt - - saivat pienestä pitäen enemmän vastuuta kodin lukuisista askareista. Pienempien sisarusten hoitaminen oli itsestään selvää.

- - Me tytöt olimme lapsia nïn kauan, kunnes syntyi pikekusisko tai veli, sen jälkeen meistä tuli lapsen - - boitajia - - Koulu oli melkein kuin lomaa, iban omaa aikaa.

Tyttöjen maailma oli täynnä kieltoja, sääntöjä ja määräyksiä. Tytöt-- eivät- - istuneet jouten, vaan parsivat ja paikekasivat, pitivät huolta vaatteista, omistaan ja toisten. Lauantai-iltaisin kun naisväki oli navettatöillä, minä isompana tyttönä tarkistin äidin meille jokaiselle katsomat pubtaat vaatteet. - Jos niissä vaatteissa oli reikiä taikka ratkeamia, ne piti tietenkin korjata ja paikata. Veli, joka oli ainoa poika - - pääsi paljon helpommalla. Sen kun vaan veti pubtaat vaatteet pä̈allensä $--^{52}$

Aikuisena Saara ajattelee, että hänestä kasvoi "aikamoinen huolehtija". ${ }^{53}$ Myös Sisko kertoo omaksuneensa äidiltään huolehtimisen mallin. Hän hoiti äitiään tämän ollessa vanha, samoin kuin Siskon äiti oli 
hoitanut omaa äitiään tämän viimeisinä vuosina. ${ }^{54}$ Sisko vaikuttaa tekstinsä perusteella olevan vastuun kantava ja huolehtiva selviytyjä.

$$
\begin{aligned}
& \text { [Ä]itini- - boiti anoppinsa ja ä̈tinsä viimeiset elinvuodet haudan lepoon saakka. Auttoi minua lap- } \\
& \text { senhoidossa. -- Äidiltäni olen omaksunut elämäni kantavana voimavarana sosiaalisunden, auttamisen } \\
& \text { halun, ja läheisten hoitamisen omassa kodissa. }{ }^{55}
\end{aligned}
$$

Kahdella lapsettomista naisista ei tätä roolia ilmene, mikä johtunee yksinkertaisesti siitä, ettei heillä ole elämässään ketään huolehdittavia. Tuulalla huolehtijan rooli on kuitenkin vahva, sillä hän kantaa huolta sekä alkoholistiveljestään että dementoituneesta isästään.
Isäni hoito oli raskasta. Dementoituessaan bänen persoonallisuntensa munttui - - Vaikein asia elä- mässäni oli kuitenkin veljeni alkoholisoituminen. - - Toisaalta olin bädissäni, toisaalta minua suntutti. Isän hoitamisessa oli tarpeeksi tekemistä, miksi veljeni- - vielä vaikeutti asioita. - - Tunsin väsymystä, joka ei parantunut levolla. ${ }^{56}$

Suurten ikäluokkien naiset ovat usein omaksuneet huolehtijan roolin, mutta moni heistä vaikuttaa ajautuneen siihen automaattisesti, eikä kyse ole ollut mistään sisältä kumpuavasta huolehtimisen palosta. Tämä voi johtua sekä opitusta mallista että yhteiskunnallisista rakenteista. ${ }^{57}$

\section{Kaksoistaakka ja naisten ja miesten tasa-arvo}

Toisin kuin Yhdysvalloissa, Suomessa naiset eivät ryhtyneet toisen maailmansodan seurauksena sankoin joukoin kotirouviksi, vaikka hetkellisesti etenkin naimisissa olevien naisten oletettiin luopuvan työpaikoistaan, jotta miehille riittäisi töitä. ${ }^{58}$ Vuonna 1948 syntynyt Seija muistelee vanhempiensa työnjakoa:

$$
\begin{aligned}
& \text { Isä oli sahalla lajittelijana ja Äiti joskus kesäisin oli ylösottajana, mutta talvet oli kotona ja hoiti meitä } \\
& \text { lapsia--Ä̈dillä riitti tö̈tä hoitaa meitä neljää lastaan, kun Isä kulki tienestissä, ja sïhen aikeaan ei } \\
& \text { Äidit paljon olleet töissä. }{ }^{59}
\end{aligned}
$$

Vielä 1970-luvulla äitien työssäkäynnin nähtiin olevan sopivaa vain olosuhteiden pakosta. ${ }^{60}$ Perinteistä sukupuolten välistä työnjakoa esiintyy jossain määrin myös suurten ikäluokkien naisten omaelämäkerroissa. Kotiäiti Helena kertoo:
Erik alkoi olla pidemmillä työmatkoilla ja Helena oli päivät ja yöt ykesin lastensa kanssa. - - Sitten he munttivat - - etäämmälle keskustan palveluista ja Erik alkoi ybä enenevässä määrin hoitaa kodin ulkopuolisia asioita - - Helena käpertyi entistä enemmän kotiin. Erik,joutui ottamaan lisäksi iltatöitä - - Kotiäitinä Helena tunsi olevansa ykesin oman perbeensä kanssa $--^{61}$

Sotien jälkeen Suomen valtio tuki yhtä aikaa sekä äitien työssäkäyntiä että kotiin jäämistä, sillä heidän panostaan tarvittiin sotakorvausten maksamisessa. ${ }^{62}$ Loppujen lopuksi suomalaisnaisten työelämään siirtyminen kiihtyi sotien myötä. ${ }^{63}$ Naisten piti yhdistää jälleenrakentajan ja perinteisen naisen roolit, ja äidit joutuivat yhä useammin sovittamaan yhteen työn ja perheen. ${ }^{64}$

Vaikka kaksoistaakalla tarkoitetaan yleensä lastenhoidon ja ansiotyön ristiriitaa, sopii käsite mielestäni myös maalaisemäntien tilanteeseen. ${ }^{65}$ Kuten aiemmin tuli esille, lasten saaminen oli emännille raskasta, kun samaan aikaan joutui työskentelemään navetassa ja peltotöissä. ${ }^{66}$ Hyvinvointivaltiokehityksen 
myötä lastenhoidon järjestäminen muuttui helpommaksi, mutta se ei auttanut kotitöiden tekemisessä tai lapsista huolehtimisessa töiden jälkeen. ${ }^{67}$

Suurin osa omaelämäkerta-aineiston naisista elää työn ja perheen ristipaineessa. Helena H. kertoo lapsiperhearjestaan odottaessaan vauvaa, kun mies oli palannut ulkomailta:

Talvi toi mieheni takaisin, pojan armeijasta - - Itse kävin töissä ja hoidin viiden hengen talouttamme. Olin väsynyt ja masentunut, koska en ollut saanut öitäni nukutuksi, koska pienokaisemme oli kovin vilkas myös öisin-- Jaksoin kuitenkin olla työssä aina normaaliin äitiyslomaan saakka. - - Äitiysloma oli täyttä työtä kahden pienen lapsen kanssa ja olihan perbeemme nyt kuusibenkinen. Usein raahasin kaupasta selkä kipeänä ruokaa - - Menin tö̈hin heti äitiysloman loputtua ja ybä edelleen nukuin yöni huonosti. - - Tajusin kyllä, että minun pitäisi saada vähän vapaata tästä kaikesta, mutta kukaan ei ottaisi minun tehtäviäni huoleksi. Niinpä kuljin vain työn ja kodin väliä ja iltaisin toubusin lasten kanssa yrittäen siinä sivussa boitaa kotityöt. ${ }^{68}$

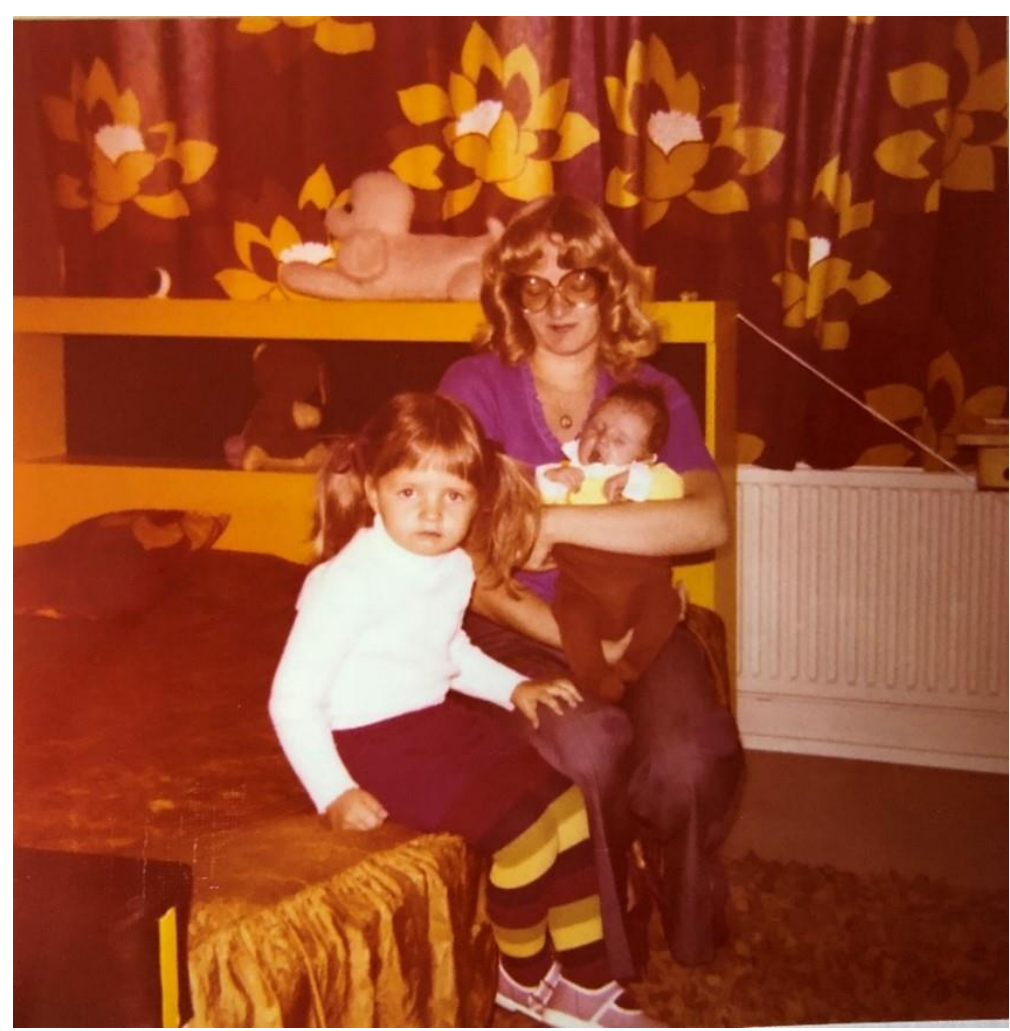

Kuva 4. Edellisessä kuvassa etualalla ollut, v. 1950 syntynyt nainen lapsineen kodissaan Labdessa v. 1977. Yksityinen kuva-albumi.

Kaksoistaakkaa ei aineistossa paljoa kyseenalaisteta eikä se tunnu vaikuttavan naisten avioliiton tilaan. Perheen toimeentulon turvaamiseksi nimimerkki Helenan mies toivoo tämän käyvän töissä lapsista ja kodista huolehtimisen lisäksi. Helena jatkaa tarinaansa:

Isommat lapset läbtivät omiïn asuntoibin - - Taloustöissä kahden aikuisen lähtö tuntui helpotuksena. Kun ennen kannoin monella kassilla ruokaa viikonlopuksi, nyt riitti yksi. - - Avioliittomme pysyi onnellisena ja keskinä̈nen rakkaus tasoitti monta särmää. Mieheni luottamustoimet olivat vain vuosien myötä lisääntyneet ja minä olin edelleen lasten kanssa iltaisin kotona. ${ }^{69}$ 
Aineistossa on jossain määrin havaittavissa myös kehitystä tasa-arvoisempaan työnjakoon parisuhteen sisällä. Silti isällä on äitiä suuremmat vapaudet mennä ja tulla opiskelun, työn tai mielihalujen niin edellyttäessä. Muu perhe toimii isän ehdoilla. ${ }^{70}$ Saaran avioliitossa työnjako on hivenen modernimpi - tosin olosuhteiden pakosta - kun mies jäi hoitamaan perheen kuopusta työkyvyttömyyseläkkeelle jouduttuaan. ${ }^{71}$ Ellan mies vei yhtä perheen kolmesta lapsesta hoitoon. ${ }^{72}$ Sopuli alleviivaa työnjaon olleen tavanomaista tasaisempi jo alun alkaen:

Avioliiton alussa muotoiltiin perheen siivoustottumukset. - - Kotityöt tebtïn ybdessä. Mieheni oli kiinnostunut ruoanlaitosta ja kyseli miten ruskea kastike tehtiin, korostan, että hän oli itse kïinnostunut asiasta. $^{73}$

Myös Sopuli joutui kuitenkin kaksoistaakan ikeeseen ja perheen vastuunkantajaksi, kun miehellä taas oli enemmän vapauksia. Näin sujui perheen arki 1970-luvun loppupuolella:

Tyttären synnyttyä - - [s]ain työstä 3 kk lomaa - - kun olin työssä laskettuun pä̈vään. Oli asuntolainaa ja tö̈bin oli mentävä, jotta selviäsimme. Työpäivän aikana maitoa valui rinnoista - - Pienten lasten kanssa elämänpiiri supistui lähiympäristöön.

- - Yritin päästä tö̈bin, mutta töitä ei löytynyt. [Pääsin] ammattikurssille - - Lapset sain kunnalliseen perhepä̈vähoitoon - - Rankekaa oli ylesin viedä lapset hoitoon ja hakea, yöllä oli opiskeltava. Onneksi välissä oli kesä ja [mies] sai töitä ja oli kesän kotona. Taas sykesyllä hain tö̈tä, ja pääsinkin työllisyystöibin toimistoon osa-päiväiseksi.

Vuoden 1978 alussa mieheni läksi opiskelemaan, viikot toisella paikkakunnalla - - arkisin minulla oli minunttiaikataulu, lapset aamulla perhepäivähoitoon, työpaikalle ja työpäivän jälkeen kotiin. - En tiedä miten selvisin, vastun oli kannettava.

Siinä vuodet vierivät arkirutïneissa-- Paljon ei jäänyt aikaa barrastuksiin. Illalla töiden jälkeen kun yritin tiskata molemmat lapset roikekuivat helmoissa. Vuosien aikana olin - - saanut ratkaista useat perhettämme koskevat asiat ykesin. ${ }^{74}$

Suurten ikäluokkien naiset ovat jossain määrin irtautuneet äitiensä sukupolven normeista. Helena H. kertoo keski-iän "kapinastaan":

[H]uomasin kolmenkymmenenviiden ikävnoden jälkeen itsessäni unsia piirteitä. Halusin enemmän aikaa itselleni. Seköo on sitä keski-iän kriisiä? Koko mun perbe meni ja harrasti ja minä vain olin buoltojoukkona. Halusin opiskella, käydä teatterissa, konserteissa, halusin boitaa itseäni. - - Kyselin itseltäni - - mitä nämä undet ajatukset aibeuttavat perbeelleni. - - Oli minun kapinani aika. - Kaksikymmentä vuotta tätä samaa raatamista. Halusin pois koko kuviosta. Pubuin kotona miehelleni, mutta en saanut oikein innostunutta vastausta. - - [M]ieheni miettii - - selviämmekö talven ajan ilman minun ansiotani.$^{75}$

Kapinahaluista huolimatta katkelmassa näkyy vastuunkanto ja vahva perheestä huolehtimisen tarve. Huolimatta miehensä hangoitteluista Helena H. päätti aloittaa opinnot. Silti kotitaloustyöt ja perheen ruokkiminen olivat edelleen täysin hänen harteillaan. 
Minä nautin, todella. Oliko koulu ennen näin hauskaa[?] - - Aamuisin lähdin puoli seitsemän kotoa ja palasin illalla puoli viisi. Aikea e i jäänyt liikea muulle kuin läksyille. Sïnä sivussa laitoin perbeelle ruoan ja viikonloppuisin tein munt kotityöt. $--^{76}$

Pitkän neuvonpidon päätteeksi miehensä kanssa Helena H. sai hieman vapauksia, kunhan perhe ei siitä kärsi. Mies sai osallistua aktiivisemmin kodin ulkopuoliseen elämään.

Monien keskustelujen jälkeen olemme mieheni kanssa päässeet jonkinlaiseen ybteisymmärrykseen siitä, kuinka paljon voin olla kotoa poissa iltaisin ilman, että perbe siitä kärsii. Yhden illan viikossa olen varannut jumpalle. - - Osallistun omalla pienellä panoksellani ay-toimintaan. Se on mielenkiintoista ja haastavaa, vaikeka olenkin halunnut pysyä siellä bieman sivussa, sillä helposti saa liikaa tebtäviä ja meidän perheessä riittää tällä hetkellä y lesi erittäin aktiivinen osallistuja ja vaikuttaja [mies]. Käyn paljon teatterissa ja konserteissa. Aina kun vain aika sallii. ${ }^{77}$

Vaikka Ainolla oli miehensä kanssa perinteinen työnjako, kertoi hän silti olleensa aina tasa-arvoinen miesten kanssa. ${ }^{78}$ Kuitenkin Aino tunnustaa miehensä jumiutuneen perinteiseen työnjakoon ja pohtii, millaisia muutoksia heidän pojillaan on edessään:

Kuvittelin kasvattavani pojistani miehiä, jotka eivät välttele siivoamista, tiskaamista eivätkä runanlaittoa. Nytpelkä̈än, että heistä on tulossa melkoisia sovinisteja. He ottavat mallia isästään, joka on ottanut miehen mallin nïltä ajoilta, kun naisten ja miesten työt olivat tarkasti jaettuja. En ole pystynyt munttamaan mieheni ajatuksia ja olen oppinut hyväkesymään bänet sellaisenaan. Olen yrittänyt muistuttaa pojilleni, että sukupolveni naiset ovat viimeinen ikäluokka, joka vielä "passaa" perbeenjäseniään minun laillani. - - Heidän vaimonsa tulevat vaatimaan miebiltään tasapuolista osallistumista kotitöibin ja pitävät sitä todennäköisesti itsestäänselvyyten $\ddot{a}^{79}$

Tuula ei halunnut perustaa perhettä. Viimein hän löysi itselleen sopivan parisuhteen:

Poikaystäviä oli ja meni, mutta jotain minä edelleen elämältä odotin. En missään tapanksessa balunnut sitoutua maataloibin enkä varsinkaan minjäksi - - Pitkän jabkailun jälkeen pää̈in munttaa ystäväni kanssa ybteen. - - Mikä parasta, hän ei latista minua ja estä harrastuksiani vaan kannustaa nïssä. ${ }^{80}$

"[N]ainenkin on vastuussa siitä, jääkö hän miehensä jalkoihin, kynnysmatoksi, vai haluaako hän elää ja löytää itsensä”, tuumaa vapaaehtoisesti lapseton, vuonna 1948 syntynyt Liisa. ${ }^{81}$ 


\section{Nykypäivän naisen taakat}

Naisen rooli arjen vastuunkantajana on pitkän historiallisen kehityskulun seurausta. Hanna Ranssi-Matikaisen mukaan naiset ovat oppineet uhrautuvan perheenäidin mallin omilta äideiltään. Myös vanhempainvapaajärjestelmä on tukenut eriarvoista asetelmaa, sillä sen aikana kotityön jakaminen on usein vakiintunut naisen harteille, eivätkä roolit usein muutu lasten kasvaessakaan. ${ }^{82}$ Vaikka tilannetta yritetään muuttaa esimerkiksi perhevapaiden tasaisemmalla jakamisella, ${ }^{83}$ kotitaloustöiden jakautuminen on yhä epätasaista naisten ja miesten välillä. Suomalaisnaisilta kuluu yli tuplasti enemmän aikaa ruoanlaittoon, siivoamiseen ja lapsista huolehtimiseen kuin miehillä. ${ }^{84}$

Lisäksi tilastoissa ei näy metatyö, jota naiset niin ikään tekevät miehiä enemmän. Metatyö on jatkuvaa näkymätöntä aivotyötä, valmistelua ja arjen organisoimista. ${ }^{85}$ Naisten tekemään metatyöhön kuuluvat esimerkiksi ennakoiminen, valvonta, lapsista huolehtiminen, logistiikka sekä aikatauluttaminen. ${ }^{86}$ Metatyö kasvattaa kokonaistyöaikaa ja johtaa eriarvoistumiseen ja naisten uupumiseen. ${ }^{87}$ Aihetta tutkineen Susanna Luukisen mukaan naiset kuitenkin vähättelevät uupumustaan eivätkä halua vaatia miehiltään liikaa ja pohtivat, "olisiko vika sittenkin heissä itsessään." ${ }^{88}$ Naiset ovat myös ylpeitä jaksamisestaan, uhrautumisestaan sekä lastensa ja miestensä asioiden hoitamisesta. On tärkeää pärjätä ja selviytyä itse. ${ }^{89}$

Ylisuorittaminen ja uupuminen ovat olleet esillä julkisessa keskustelussa 2010- ja 2020-luvuilla. Niiden taustalla uskotaan olevan esimerkiksi vaikenemisen kulttuuria, tunnollisuutta, velvollisuudentunnetta ja korkeaa työmoraalia $-{ }^{90}$ kaikki mentaliteetteja, jotka vahvistuivat talvi- ja jatkosodan ja jälleenrakennuksen myötä. Naiset stressaantuvat ja uupuvat miehiä useammin. Uupumus voi johtaa mielenterveysongelmiin, ${ }^{91}$ jotka ovat yleistyneet etenkin naisilla. Tämän uskotaan johtuvan työ- ja perhe-elämän vaatimuksista. Miehet puolestaan kokevat suorituspaineita varsinkin työnteosta ja perheen elättämisestä. ${ }^{92}$ Vaikka naisista on tullut lähes tasavertaisia miesten kanssa työelämässä, kodista ja lapsista huolehtiminen on edelleen enemmän naisten vastuulla. Ylisuorittaminen ja uupuminen ovat monen tekijän summa. Vaikka niiden ei voida ajatella olevan sodan seurausta, voidaan niiden nähdä olevan osa ylisukupolvista jatkumoa, jota sota vahvisti.

\section{Lopuksi}

Kirjalliseen haastatteluun vastanneet naiset kuvailevat oppineensa äideiltään etenkin ahkeruutta, vastuuntuntoa, huolehtimista ja sitkeyttä. Vahvan suomalaisnaisen ideaali elää suurten ikäluokkien kokemuksissa. Kuvauksissa näkyvät rakennemuutos sekä sukupolvien välillä tapahtunut muutos naisen roolissa - sotasukupolven maalaisnaiset olivat sidottuja kotiin, suurten ikäluokkien naiset osallistuivat lisäksi usein työelämään ja heillä oli enemmän vapaa-aikaa - vaikka perheellisillä naisilla kaksoistaakka sitä rutkasti rajoittikin. $^{93}$

Vaikka toinen maailmansota osaltaan lisäsi mahdollisuuksia naisten ja miesten tasa-arvoon, lisäsi se todellisuudessa monella tapaa eriarvoisuutta. Vaikka viime vuosikymmeninä kotitöiden jakautuminen on hieman tasaantunut naisten ja miesten välillä ja Suomen päivähoito- ja vanhempainvapaajärjestelmät voisivat mahdollistaa tasa-arvon, suurempi murros on yhä toteutumatta. ${ }^{94}$ Lainsäädäntö ja sosiaalipolitiikka eivät yksistään riitä ratkaisemaan ongelmaa. ${ }^{95}$

Kaikkea ei voi eikä pidä selittää sodalla, vaikka eittämättä toisella maailmansodalla olikin suuria vaikutuksia sekä ihmisten arkeen että yhteiskuntaan laajemmin. Tarkastellut teemat ovat monisyisiä ja monimutkaisia, usein moneen asiaan sekä toisiinsa kietoutuneita. Toisaalta sota ei itsessäänkään ole yksinkertainen, vaan äärimmäisen moniulotteinen ilmiö. 
Tutkijat ovat yhtä mieltä siitä, että sodilla on kauaskantoisia, ylisukupolvisia vaikutuksia. Tuomalla näitä vaikutuksia ilmi voidaan tiedostaa yhteiskunnassamme vallitsevia, mahdollisesti haitallisia mentaliteetteja ja toimintatapoja ja sitä kautta muuttaa niitä niin yksilön kuin valtionkin tasolla. Eriarvoisuutta ylläpitävien ongelmien tiedostaminen ja niistä puhuminen ovat ensiaskelia niiden ratkaisemiseen. ${ }^{96}$ 
${ }^{1}$ Sini-Emilia Asikainen, Toisen maailmansodan ylisukupolviset vaikutukset suomalaisen naisen rooliin ja mentaliteettiin, Helsingin yliopisto (2020). http://urn.fi/URN:NBN:fi:hulib-202011234558

2 Pia Olsson, Women in Distress. Self-understanding among 20th-century Finnish rural women (Münster: LIT Verlag, 2011), 75-81; SeijaLeena Nevala ja Kirsi-Maria Hytönen, "Toimet, työt ja taakat - Perhe-elämä maaseudulla sodan jälkeen”, teoksessa Raubaton rauba. Suomalaiset ja sodan päättyminen 1944-1950, toim. Ville Kivimäki \& Kirsi-Maria Hytönen (Tampere: Vastapaino, 2015, 150-173), 151-152; Naiset olivat tarvittaessa tehneet miesten töitä jo ennen sotaa. Ann-Catrin Östman, "Mekanisoinnin ensimmäinen aalto", teoksessa Suomen maatalouden historia, osa II, toim. Matti Peltonen (Helsinki: SKS, 19-76), 59-65; Vielä suurten ikäluokkien lapsuudessa 1950-luvulla koneet olivat maaseudulla harvassa. Antti Häkkinen, Eila Linnanmäki ja Pirkko Leino-Kaukiainen, "Suomi, johon suuret ikäluokat syntyivät", teoksessa Suuret ikäluokat, toim. Antti Karisto (Tampere: Vastapaino, 2005, 61-91), 81-82.

3 Ville Kivimäki ja Anssi Männistö, Sodan särkemä arki (Helsinki: WSOY, 2016), 70-71.

${ }^{4}$ Nevala ja Hytönen 2015, "Toimet, työt ja taakat", 151, 158.

${ }^{5}$ Kivimäki ja Männistö 2016, Sodan särkemä arki, 81, 87.

${ }^{6}$ Jenni Kirves, Ville Kivimäki, Sari Näre ja Juha Siltala, "Sodassa kasvaneiden tunneperintö", teoksessa Sodan kasvattamat, toim. Sari Näre, Jenni Kirves ja Juha Siltala (Helsinki: WSOY, 2010, 387-410), 395; Olsson 2011, Women in Distress, 113-123; Sari Näre, "Naiset ja miehet sodan pyörteissä", teoksessa Kotirintama, toim. Martti Turtola (Helsinki: WSOY, 2018, 8-31), 11, 14; Antti Malinen, Sodan satuttamat. Osa 2. Naiset kantoivat raskaita taakkoja, Yle Areena, 23.10 .2019 (https://areena.yle.fi/1$\underline{50273219}$ avattu 30.7.2021); Antti Malinen, "Ristinkantajat. Maalaisemäntien sisäiset ristiriidat ja niiden sielunhoidollinen käsittely toisen maailmansodan jälkeisessä Suomessa", teoksessa Eletty historia. Kokemus näkökulmana menneisyyteen, toim. Johanna Annola, Ville Kivimäki ja Antti Malinen (Tampere: Vastapaino, 2019, 367-396), 368, 376.

${ }^{7}$ Olsson 2011, Women in Distress, 61-64; Pia Olsson, "Nainen ja työn muuttuvat normit", teoksessa Kotirintama, toim. Sonja Hagelstam ja Martti Turtola (Helsinki: WSOY, 2018, 150-183), 151-153; Malinen 2019, "Ristinkantajat”, 369; Seija Aunila, "Kuinka naistenlehdestä tuli osa sotapropagandaa. Naisihanteen muodostuminen ja muokkautuminen Kotiliesi-lehdessä toisen maailmansodan aikana", Jyväskylän yliopisto (2020), 252. http://urn.fi/URN:ISBN:978-951-39-8256-0

${ }^{8}$ Asikainen 2020, Toisen maailmansodan ylisukupolviset vaikutukset suomalaisen naisen rooliin ja mentaliteettiin, 15, 29.

${ }^{9}$ Yhden vanhemmat muuttivat maalta tehdaskauppalaan töihin, minkä vuoksi hänen lapsuutensa poikkeaa muista. Satasärmäinen nainen, 1991, Suomalaisen Kirjallisuuden Seuran kansanrunousarkisto (SKS KRA SATA 1991).

10 Asikainen 2020, Toisen maailmansodan ylisukupolviset vaikutukset suomalaisen naisen rooliin ja mentaliteettiin, 23-25.

11 Ville Kivimäki, Murtuneet mielet. Taistelu suomalaissotilaiden hermoista 1939-1945 (Helsinki: WSOY, 2013), $319,321$.

12 Tiina Kinnunen ja Ville Kivimäki. "Sota sosiaalisena ja kulttuurisena ilmiönä. Toinen maailmansota ja uusi sotahistoria suomalaisissa väitöstutkimuksissa". Historiallinen aikakauskirja 116:4 (2018, 373-383), 382. http://urn.fi/URN:NBN:fi:ELE$\underline{016755803}$

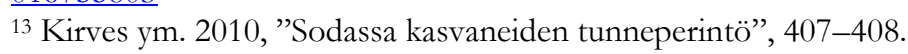

${ }^{14}$ Nevala ja Hytönen 2015, "Toimet, työt ja taakat”, 170; Antti Malinen ja Tuomo Tamminen, Jälleenrakentajien lapset (Helsinki: Gaudeamus, 2017), 164.

15 SKS KRA SATA 1991, 11147, synt. 1947.

16 SKS KRA SATA 1991, 18717, synt. 1950.

17 SKS KRA SATA 1991, 10479, 10482, synt. 1948.

${ }^{18}$ Kirjallinen haastattelu 31.5.2020, Aino, synt. 1950.

${ }^{19}$ SKS KRA SATA 1991, 4119, synt. 1949.

20 Malinen 2019, "Ristinkantajat", 376.

21 Olsson 2011, Women in Distress, 76-78; Nevala ja Hytönen 2015, “Toimet, työt ja taakat”, 151-153, 167.

22 Ilona Kemppainen, Isänmaan uhrit. Sankarikuolema Suomessa toisen maailmansodan aikana, (Helsinki: SKS, Bibliotheca Historica 102, 2006), 13; Antero Holmila, "Jälleenrakentamisen narratiivit ja niiden muotoutuminen Suomen lehdistössä 1944-1945". Elore, 15/2 (2008, 1-20), 9-10, 16 https://doi.org/10.30666/elore.78743; Olsson 2011, Women in Distress, 118; Nevala ja Hytönen 2015, "Toimet, työt ja taakat", 167-170; Antti Malinen, "Marriage Guidance, Women and the Problem(s) of Returning Soldiers in Finland 1944-1946". Scandinavian Journal of History, 43/1 (2018, 112-140), 127 https://doi.org/10.1080/03468755.2017.1379173; Malinen 2019, "Ristinkantajat", 376.

${ }_{23}$ Olsson 2018, "Nainen ja työn muuttuvat normit", 168-170.

${ }_{24}$ Antero Holmila ja Simo Mikkonen, Suomi sodan jälkeen. Pelon, katkeruuden ja toivon vuodet 1944-1949 (Jyväskylä: Atena, 2015), 116-122;

${ }^{25}$ Malinen 2018, "Marriage Guidance, Women and the Problem(s) of Returning Soldiers in Finland 1944-1946", 124-125; Malinen 23.10.2019, "Sodan satuttamat. Osa 2".

${ }^{26}$ Olsson 2011, Women in Distress, 62.

${ }^{27}$ Kirjallinen haastattelu 18.5.2020, Sopuli, synt. 1947.

${ }^{28}$ Kirjallinen haastattelu 12.5.2020, Ella, synt. 1950.

${ }^{29}$ Kirjallinen haastattelu 26.5.2020, Saara, synt. 1947.

30 SKS KRA SATA 1991, 10490-10502, synt. 1948.

${ }^{31}$ SKS KRA SATA 1991, 312-314, synt. 1947.

32 SKS KRA SATA 1991, 306-329; Kirjallinen haastattelu 20.5.2020, Sisko, synt. 1947.

33 SKS KRA SATA 1991, 315-316, synt. 1947. 
34 SKS KRA SATA 1991, 8362, synt. 1949.

${ }^{35}$ Malinen 2019, "Ristinkantajat", 390.

${ }^{36}$ Kortteinen, Matti. Kunnian kenttä. Suomalainen palkkatyö kulttuurisena muotona, (Helsinki: Hanki ja jää, 1992), 47-49, 69-72.

${ }^{37}$ SKS KRA SATA 1991, 8363, synt. 1949.

38 SKS KRA SATA 1991, 4134-4144, synt. 1949.

${ }^{39}$ Myös Matti Kortteinen on tehnyt tämän huomion. Kortteinen 1992, Kunnian kenttä, 52.

${ }^{40}$ Kirjallinen haastattelu 18.5.2020, Sopuli, synt. 1947.

${ }^{41}$ Holmila 2008, "Jälleenrakentamisen narratiivit", 9-11; Olsson 2011, Women in Distress, 63, 119-121; Nevala ja Hytönen 2015,

"Toimet, työt ja taakat", 152; Malinen 2019, "Ristinkantajat", 368-369, 376-383.

42 SKS KRA SATA 1991, 10506.

${ }^{43}$ Asikainen 2020, Toisen maailmansodan ylisukupolviset vaikutukset suomalaisen naisen rooliin ja mentaliteettiin, 33.

${ }^{44}$ Kirjallinen haastattelu 31.5.2020, Aino, synt. 1950.

45 SKS KRA SATA 1991, 11175-11176, synt. 1947.

${ }^{46}$ Kirjallinen haastattelu 18.5.2020, Sopuli, synt. 1947.

${ }^{47}$ Olsson 2011, Women in Distress, 121-123.

48 John Bowlby, A Secure Base. Parent-Child Attachment and Healthy Human Development (New York: Basic Books, 1988), 2.

${ }^{49}$ Malinen ja Tamminen 2017, Jälleenrakentajien lapset, 176.

50 SKS KRA SATA 1991, 10797, synt. 1950.

51 SKS KRA SATA 1991, 4126.

52 Kirjallinen haastattelu 26.5.2020, Saara, synt. 1947.

${ }^{53}$ Kirjallinen haastattelu 26.5.2020. Saara, synt. 1947.

54 SKS KRA SATA 1991, 309; Kirjallinen haastattelu 20.5.2020, Sisko, synt. 1947.

${ }^{55}$ Kirjallinen haastattelu 20.5.2020, Sisko, synt. 1947.

56 SKS KRA SATA 1991, 11171-11172, synt. 1947.

${ }_{57}$ Asikainen 2020, Toisen maailmansodan ylisukupolviset vaikutukset suomalaisen naisen rooliin ja mentaliteettiin, 37.

58 Susan Hartmann, "Prescriptions for Penelope: Literature on women's obligations to returning World War II veterans". Women's Studies 5 (1978, 223-239), 223-230 https://doi.org/10.1080/00497878.1978.9978450; Marjatta Rahikainen, ”'Naiset näkyvät Suomessa tekevän vaikka mitä", teoksessa "Työllä ei oo kukekan rikastunna". Naisten töitä ja toimeentulokeinoja 1800- ja 1900-luvulla, toim. Marjatta Rahikainen ja Tarja Räisänen (Tietolipas 176. Helsinki: SKS, 2001, 17-35), 32; Anu Suoranta, "Lama iski - Naiset töihin! 1930-luvun lama ja naisten työmarkkina-asema". Teoksessa "Työllä ei oo kukeaan rikastunna". Naisten töitä ja toimeentulokeinoja 1800- ja 1900-luvulla, toim. Marjatta Rahikainen ja Tarja Räisänen (Tietolipas 176. Helsinki: SKS, 2001, 146-160), 146, 157-158; Nevala ja Hytönen 2015, ’Toimet, työt ja taakat”, 155-156, 162.

${ }^{59}$ SKS KRA SATA 1991, 17304, synt. 1948.

${ }^{60}$ Antti Häkkinen ja Marjatta Rahikainen, "Naisten työnteon ja toimeentulon tutkimuksesta”, teoksessa "Työllä ei oo kukkaan rikastunna". Naisten töitä ja toimeentulokeinoja 1800- ja 1900-luvulla, toim. Marjatta Rahikainen ja Tarja Räisänen (Tietolipas 176 , Helsinki: SKS, 2001, 7-16), 8.

${ }^{61}$ SKS KRA SATA 1991, 8360-8361, 8363, synt. 1949.

${ }^{62}$ Nevala ja Hytönen 2015, "Toimet, työt ja taakat", 162.

${ }^{63}$ Antti Häkkinen Eila Linnanmäki ja Pirkko Leino-Kaukiainen, "Suomi, johon suuret ikäluokat syntyivät", teoksessa Suuret ikäluokat, toim. Antti Karisto (Tampere: Vastapaino, 61-91), 64-65; Olsson 2011, Women in Distress, 63; Kirsi-Maria Hytönen Ei elämääni lomia mabtunut. Naisten muistelukerrontaa palk.katyöstä talvi-ja jatkosotien ja jälleenrakennuksen aikana. (Joensuu: SKTS, 2014), 195.

${ }^{64}$ Janne Haikari, “Kun sota loppuu mutta velvoitteet jatkuvat. Suomen jälleenrakentaminen Kotiliesi-lehdessä 1940-1941”, teoksessa Kun sota on obi. Sodista selviytymisen ongelmia ja nïden ratkaisumalleja 1900-luvulla, toim. Petri Karonen ja Kerttu Tarjamo (Helsinki: SKS 2006, 266-309), 297; Kirves ym. 2010, "Sodassa kasvaneiden tunneperintö", 408.

${ }_{65}$ Asikainen 2020, Toisen maailmansodan ylisukupolviset vaikutukset suomalaisen naisen rooliin ja mentaliteettiin, 39.

66 Olsson 2011, Women in Distress, 122.

${ }^{67}$ Hannu Pääkkönen ja Riitta Hanifi, Ajankäytön muntokset 2000-luvulla (Helsinki: Tilastokeskus, 2011), 26 ISBN 978-952-244331-1 (pdf); Hanna Ranssi-Matikainen, Yhdessä sittenkin: Kokemukset erokrïisistä, vertaistuesta ja muntoksesta parisubteessa (Kirkon tutkimuskeskuksen julkaisuja 116, 2012).

${ }^{68}$ SKS KRA SATA 1991, 4143, synt. 1949.

${ }^{69}$ SKS KRA SATA 1991, 4145-4146, synt. 1949.

${ }^{70}$ Asikainen 2020, Toisen maailmansodan ylisukupolviset vaikutukset suomalaisen naisen rooliin ja mentaliteettiin.

${ }^{71}$ SKS KRA SATA 1991, 5236, synt. 1947.

${ }^{72}$ SKS KRA SATA 1991, 18723-18724, 18726, synt. 1950.

73 SKS KRA SATA 1991, 10128, synt. 1947.

${ }^{74}$ SKS KRA SATA 1991, 10132-10135; Kirjallinen haastattelu 18.5.2020. Sopuli, synt. 1947.

75 SKS KRA SATA 1991, 4146, 4148, synt. 1949.

${ }^{76}$ SKS KRA SATA 1991, 4148, synt. 1949.

77 SKS KRA SATA 1991, 4158, synt. 1949.

${ }^{78}$ SKS KRA SATA 1991, 8981, synt. 1950.

${ }^{79}$ SKS KRA SATA 1991, 8979-8980, synt. 1950. 
80 SKS KRA SATA 1991, 11152, 11178-11181, synt. 1947.

81 SKS KRA SATA 1991, 8280, synt. 1948.

82 Ranssi-Matikainen 2012, Yhdessä sittenkin, 9.

${ }^{83}$ THL. Terveyden ja hyvinvoinnin laitos. "Perhevapaiden käyttö ja kustannukset". (29.6.2020, https://thl.fi/fi/web/sukupuolten-tasa-arvo/tasa-arvon-tila/perheet-ja-vanhemmuus/perhevapaiden-kaytto-ja-kustannukset avattu 30.7.2021).

84 "Ajankäytön muutokset 2010-luvulla" ei vielä ole julkaistu, joten tilastot ovat vuodelta 2009. Pääkkönen ja Hanifi 2011, Ajankäytön muutokset 2000-luvulla, 25-27.

85 Jenny Lehtinen, ”Metatyö räjäyttää äidin pään!” Kolumni. (29.10.2015, https://yle.fi/aihe/artikkeli/2015/10/29/jenny-lehtinen-metatyo-kunniaan avattu 30.7.2021).

86 Allison Daminger, “The Cognitive Dimension of Household Labor”, American Sociological Review. 84(4) (2019, 609-633), 618-624 https://doi.org/10.1177\%2F0003122419859007

${ }^{87}$ Ranssi-Matikainen 2012, Yhdessä sittenkin.

88 Susanna Luukinen, Näkymätön näkyväksi. Metakotityön sisältö ja jakamisen tavat, Helsingin yliopisto (2017), tiivistelmä, 95 http://urn.fi/URN:NBN:fi:hulib-201710315604; Susanna Luukinen, "Metakotityö uuvuttaa naiset". Ilmiö-media (20.6.2018, https://ilmiomedia.fi/artikkelit/metakotityo-uuvuttaa-naiset/ avattu 30.7.2021).

${ }^{89}$ Ranssi-Matikainen 2012, Yhdessä sittenkin, 139-140, 194-199.

${ }^{90}$ Ulla Kinnunen ja Marja Hätinen, "Työuupumus ja jaksaminen työelämässä”, teoksessa Työ leipälajina, toim. Ulla Kinnunen, Saija Mauno, Taru Maarit Feldt ja Anne Mäkikangas (Jyväskylä: PS-kustannus, 2015, 33-48), 43; Miia Roivainen, '”'Kun pitäisi jarrua painaa, niin painamme kaasua” - Uupunut salaa väsymyksen”. Yle Uutiset (27.10.2016, https://yle.fi/uutiset/3-9250657 avattu 30.7.2021).

${ }^{91}$ Katariina Salmela-Aro ja Sanna Read, "Study Engagement and Burnout Profiles Among Finnish Higher Education Students", Burnout Research 7 (2017, 21-28), 22, 26 https://doi.org/10.1016/j.burn.2017.11.001

92 Ranssi-Matikainen 2012, Yhdessä sittenkin, 159-165, 202-203; Kela. "Mielenterveyden häiriöistä johtuvien sairauspoissaolojen kasvu jatkuu jyrkkänä”. (29.1.2020, https://www.kela.fi/ajankohtaista-henkiloasiakkaat/-/asset publisher/kg5xtoqDw6Wf/content/mielenterveyden-hairioista-johtuvien-sairauspoissaolojen-kasvu-jatkuu-jyrkkana avattu 30.7.2021)

${ }_{93}$ Asikainen 2020, Toisen maailmansodan ylisukupolviset vaikutukset suomalaisen naisen rooliin ja mentaliteettiin, 63-66, 81-86.

${ }^{94}$ Ks. naisten ja miesten kotitöiden jakamisesta Pääkkönen ja Hanifi 2011, Ajankäytön muntokset 2000-luvulla, $25-27$.

${ }^{95}$ Raisa Jurva, "Independence and Vulnerability. Affective Orientations in Imagining Futurities for Heterosexual Relationships", teoksessa Affective Inequalities in Intimate Relationships, toim. Tuula Juvonen ja Marjo Kolehmainen (Oxon/New York: Routledge Research in Gender and Society, 2018, 127-140), 129.

96 Asikainen 2020, Toisen maailmansodan ylisukupolviset vaikutukset suomalaisen naisen roolïn ja mentaliteettiin, 92. 